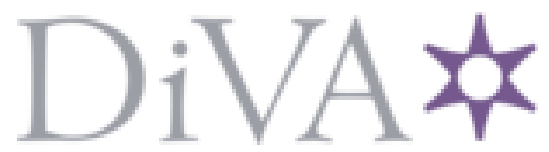

http://www.diva-portal.org

\title{
Postprint
}

This is the accepted version of a paper published in Journal of Peace Research. This paper has been peer-reviewed but does not include the final publisher proof-corrections or journal pagination.

Citation for the original published paper (version of record):

Elfversson, E. (2015)

Providing security or protecting interests?: Government interventions in violent communal conflicts in Africa.

Journal of Peace Research, 52(6): 791-805

http://dx.doi.org/10.1177/0022343315597968

Access to the published version may require subscription.

N.B. When citing this work, cite the original published paper.

Permanent link to this version:

http://urn.kb.se/resolve?urn=urn:nbn:se:uu:diva-265486 


\section{Providing security or protecting interests? Government interventions in violent communal conflicts in Africa}

\section{Introduction}

What determines central governments' strategies in relation to local conflicts within the state borders? Violent conflicts between communal groups threaten national and sometimes regional security; hence, governments should have a strong interest in containing and resolving them. Following Weber's classic definition (Weber, 1948 [1918]), a defining characteristic of the state is the monopoly over the legitimate use of force within its territory, meaning that governments are expected to deal with outbreaks of violence within their borders. Furthermore, they should be well placed to do so, as they usually control the armed forces, state resources and local governance structures. In short, we should expect the government of the affected state to be of critical importance in managing communal conflict. However, state intervention does not always take place - about a third of the cases of violent communal conflict in Sub-Saharan Africa see no intervention by the central government. This article seeks to explain this variation by asking what factors affect central decisions to make armed interventions in local communal conflicts.

I argue that in order to understand state intervention in communal conflict, we should analyse both the central government's capabilities and its strategic interests in relation to local conflicts. Communal conflict is here defined as violent conflict between non-state groups that are organized along a shared communal identity. Abdulrahman and Tar note that depending on the context and dynamics, the central government may act as a mediator or peacekeeper or as an active conflict party (2008: 190). Oftentimes the state and its agents are seen as a direct or indirect cause of communal conflicts within the country. For instance, in states where the political system is characterized by patrimonialism and is strongly organized along communal identity lines, government policies may favour one local group over another and thus spark conflict (Fjelde \& Østby, 2014; Ikpe, 2009). Communal conflict may even be directly instigated or fuelled by central or local state agents; for instance, the creation and support to tribal militias has been one strategy used by the Sudanese government to gain control over oil fields and for divide-and-rule purposes (Hutchinson, 2001). 
Yet, whereas some studies have highlighted the role of state actions and policies as causes of communal conflicts, few have systematically analysed the determinants of intervention. In-depth studies of individual countries have suggested that governments have vested interests in some communal conflicts but not others, for example based on the issues at stake and the relationship to the conflict actors (e.g. Brosché, 2014; Fratkin, 1994; Wilkinson, 2006). This may help explain the variation in state intervention. However, the external validity of these findings has not yet been systematically tested across a larger set of cases over time. Addressing this gap, this article presents the first quantitative study of state intervention in communal conflict. I argue that the strategic interests of the central government in relation to communal conflicts derive from the basic interest of rulers to remain in power and protect their power base. Building on previous research on communal conflict and state behaviour in Africa, ethnic constituencies and control over local power and resources are key among such strategic concerns. However, while strategic interests may affect the willingness to intervene, state capacity should also influence the government's decision to project its power to the location where conflict takes place. These arguments are investigated in a quantitative analysis covering sub-Saharan Africa, 1989-2010. The analysis is based on a unique new dataset on armed interventions by governments in response to communal conflict.

Communal conflicts are a frequent phenomenon and sub-Saharan Africa has been particularly affected (Sundberg, Eck \& Kreutz, 2012). These conflicts can be very deadly and often cause major disruptions of local livelihoods, at times spreading to affect entire regions. For instance, violence between ethnic communities divided along religious and indigeneity dimensions in Jos, Nigeria, has killed thousands over the past decade. Communal conflict may also spill over into other forms of political violence and even escalate into civil war (Brosché \& Elfversson, 2012). A growing literature investigates the causes and dynamics of communal violence, but conflict management and intervention in the context of communal conflict has scarcely been subject to systematic study. This article represents an important step in addressing this research gap theoretically by developing and testing propositions about the determinants of state intervention, and empirically by analysing a unique new dataset. 


\section{Explaining state intervention in communal conflict}

Communal conflict is here defined as violent conflict between non-state groups that are organized along a shared communal identity. This concept excludes purely interpersonal conflicts as well as conflicts where the state is directly involved as a primary actor. Instead, the conflict stands between groups that organize and mobilize along identity lines and use lethal violence to gain control over some disputed and perceived indivisible resource, such as land or local political power. The basis for group identification may be ethnic or religious affiliation, but the dividing line may also be between 'original' inhabitants of an area ('indigenes') and more recent 'settlers', as has often been the case in parts of West and Central Africa (cf. Fearon \& Laitin, 2011). While these identities may overlap, the key point is that the groups involved identify themselves and their opponents in terms of a certain communal identity (Brosché \& Elfversson, 2012). Substantial research on communal conflict has been conducted within the fields of anthropology and political geography, often in the form of single-case studies. Within peace and conflict research, these conflicts were for a long time understudied due to the lack of comparative data across a larger set of cases. Recent data developments, however, have provided a foundation for systematic comparative research on communal conflict. This research has so far focused mainly on the causes and dynamics of communal conflict (Brosché, 2014; Eck, 2014; Fjelde \& von Uexkull, 2012; Fjelde \& Østby, 2014; Raleigh, 2010; Theisen, 2012), while research on responses to conflict remains scarce.

\section{State intervention in communal conflict: Previous research}

If we accept the general assumption that states are responsible for upholding security within their territory, we should expect the government to intervene when violent communal conflict erupts. However, existing research illustrates that governments respond to communal conflict within their territory in very different ways, and sometimes do not take any concerted action at all (Abdulrahman \& Tar, 2008; Johansson, 2011). Security forces are commonly deployed in order to halt the violence. Sometimes, such deployment comprises a longer-term operation to disarm the conflict parties and monitor the situation after calm has been restored. For instance, the Ugandan government has since 2000 made several attempts at large-scale disarmament of pastoralist groups in the Karamoja region, with varying success (Bevan, 2008). However, in some cases there is no intervention at all. In sub-Saharan Africa 1989-2010, more than one third of communal 
conflicts reaching an intensity of at least 25 deaths saw no security force deployment by the government. How can this variation in government intervention be explained?

A growing body of case studies documents and analyses state strategies for communal conflict management. Much of this literature focuses on Africa, which has been particularly affected by communal conflicts (Sundberg, Eck \& Kreutz, 2012). These studies illustrate the great variation in state responses, and suggest that the motivations behind interventions warrant further analysis. For example, Enwerem studies state responses to religious communal violence in Nigeria, and notes that the government is often prompt in deploying security forces but less able, or willing, to tackle root causes of conflict (Enwerem, 1999). Fratkin (1994), analysing increased violence between pastoralist communities in Kenya, notes that government responses - and failure to respond - reflect vested interests in these conflicts on behalf of the central state. Also in Kenya, the marginalization and discrimination of Somali citizens likely contributed to the lack of concerted response from the central government in the face of highly escalated conflict in Wajir in the early 1990s (Ibrahim \& Jenner, 1997). However, few of these studies have taken a systematic approach to analysing intervention in communal conflict. Meanwhile, existing research on local conflict management in Africa tends to focus on broader and longer-term strategies to reduce the risk of communal conflicts, and often conflate preventive and reactive interventions. In order to better understand the way in which these conflicts are addressed, we need to specifically analyse the incentives and capabilities that underlie intervention.

So far, there is no systematic study of the determinants of state intervention in communal conflict across a larger number of cases over time. Meanwhile, a large literature on international interventions in civil wars has suggested that intervention is the result of a mixture of factors, including instrumentalist and humanitarian motivations as well as mandate and capacity for intervention (e.g. Mullenbach, 2005; Touval \& Zartman, 1985). State intervention into communal conflicts within its own territory is likely the result of similar combinations of motivational and structural factors. Below, I derive hypotheses about when intervention is more likely, based on existing arguments about strategic interest and state capacity. 
The most basic interest of the central government is to stay in power (de Mesquita et al., 2005; Gates et al., 2006). Its strategies in relation to local conflicts should be seen in this light. In the context of Africa after the Cold War, states tend to be governed by authoritarian regimes or unconsolidated democracies with weak or fragmented institutions, and often lack a firm control over parts of their territory as well as strong overarching national identities (Herbst, 2000; Jackson, 2002). To gain and remain in power, politicians often rely on patrimonial and clientelist networks and appeal to subsets of the population based on ethnic or religious identity, while employing different measures to contain the threat from potential challengers (Berman, 1998; Cederman, Wimmer \& Min, 2010; de Mesquita et al., 2005). The state's authority and power may depend on the support of some groups and be upheld through the marginalization of other groups (Raleigh 2010; Wimmer 2004). As Wilkinson (2006) has argued in the case of India, these relationships may create particular incentives for the state to act in response to some communal conflicts but not others. Intervention may not just be a tool to contain violence, but also to affect local power dynamics. Through intervention, the central government can influence the outcome, both in terms of the power balance between the involved groups and in terms of any concrete agreement regarding conflict issues.

Such strategies are likely to be informed by whether local groups constitute important political supporters, threatening opponents, or are politically irrelevant (cf. Cederman, Wimmer \& Min, 2010). In this vein, Brosché (2014) argues that bias in relation to local actors has affected how the Sudanese government both aggravates, and responds to, violent communal conflicts. Studies of communal conflict have documented numerous cases where state agents, both security forces and representatives acting as mediators, have acted in ways strongly favouring one side in the conflict or imposing a settlement or agreement in line with the state's interests. For instance, security force interventions into the conflict between Borana and Degodia in Ethiopia in the 1990s were reportedly seen as strongly one-sided and even exacerbating the conflict (Abdulahi, 2004: 15), while human rights watchdogs have documented the uneven administration of justice in relation to communal violence in Kenya under the Moi regime (e.g. HRW, 1993). As Wilkinson concludes from his research on government responses to communal violence in India, 'state governments protect minorities when it is in their electoral interest to do so' (2005: 4768). In line with this, I argue that a government is more likely to intervene if a communal conflict involves a group with which it has important patronage ties or which makes up an important 
political support base. Intervention can also be a tool for marginalizing a group that constitutes a political threat. Hence, I hypothesize that both positive and negative bias increase the likelihood of state intervention in communal conflicts.

H1a: If the government is biased in favour of a conflict party, the probability of state intervention increases.

H1b: If the government is biased against a conflict party, the probability of state intervention increases.

To retain the backing of its supporters, the state distributes a mix of public and private goods (de Mesquita et al., 2005). In the African context, land and local political positions are key among such potential patronage assets. In states where land is often communally held (i.e. leased from the state) rather than privately owned, and where local authority is often based along these same communal lines, questions of local power, local-central relations and control over land often go hand in hand (Boone, 2007: 558; Eck, 2014; Greiner, 2013; Lund, 2008). Meanwhile, local communal conflicts break out over different types of issues: for instance, local political power, access to and control over land and other valuable resources, or retaliatory livestock raiding. I hypothesize that central governments are more likely to intervene when a conflictconcerns local authority and control over land. Doing so may be one way for the state to ensure control over local resources, as well as to ensure an allocation of resources that benefits its supporters, to exclude disfavoured groups from valuable land, or to marginalize electoral opponents from local political power. Some regions of a country are also more valuable than others. Boone (2003; 2014) has shown how the economic importance of a local area conditions the scope and form of central intervention and institution building in that area. If communal conflict occurs in area which provides significant state revenue, or where prime land and businesses can be allocated in exchange for political support, the government may thus be more motivated to intervene.

H2a: If the conflict concerns land and local authority, the probability of state intervention increases.

H2b: If the conflict concerns economically important territory, the probability of state intervention increases. 
The above argument suggests that strategic interests may affect the willingness of the government to intervene. However, the decision to intervene is likely also influenced by the overall capacity of the state. States have limited resources, and the ability of the state to intervene in communal conflicts is constrained by a number of structural and political factors. Local communal conflict in Africa has to a large extent been analysed as a symptom of state weakness or failure, with the implication that conflict management is primarily an issue of building and strengthening state institutions (Allen, 1999; Mkutu, 2008: 33; Newman, 2013). This argument suggests that intervention is contingent on the availability of material and military resources. State capacity may relate to the general availability of material resources, such as economic strength and the size of the military. For instance, it has been argued that the economic crisis in the 1980s and 1990s in many African states led to decreasing capacity to exercise authority (Bates, 2008; Herbst, 1996: 123). Capacity may also relate to the ability of the government to deploy its material resources. For instance, if the state is caught up in a civil war, its capacity to allocate resources to intervene in local communal conflicts will likely decrease (cf. Odendaal, 2013:. 24-27).

H3a: If the government has strong material capacity, the probability of state intervention increases.

H3b: If the state faces other armed conflicts, the probability of state intervention decreases.

Finally, the physical location of a conflict may affect the likelihood of intervention. In line with the loss of strength gradient (LSG) argument, the ability of the central government to project its power to a specific location is a function of the resources at its disposal combined with geographic (and social) distance, where the latter affects the cost of power projection (Buhaug, 2010). As pointed out by Herbst (2000) and Boone (2003), states in Africa rarely exercise effective authority over all parts of their territory, but rather there is large variation in the degrees of control exercised by the centre in different parts of the country. For instance, areas located far from major towns and in areas with poor infrastructure are more difficult and more costly for the central government to monitor and patrol (Herbst, 2000: 23). As illustrated by pastoralist conflicts in the border areas of East Africa, conflicts in remote areas and at the borders are more difficult to manage and monitor (Frank, 2002: 72-74; Mkutu, 2008). Within civil war research it has been argued that difficult terrain is beneficial to rebels because it makes it more difficult for 
government forces to deploy against them (Collier \& Hoeffler, 2004; Fearon \& Laitin, 2003). In a similar manner, rough terrain may limit the accessibility of a communal conflict location and the ability for the government to project its power through intervention.

H4a: If the conflict takes place in a remote location, the probability of state intervention decreases.

H4b: If the conflict takes place in a mountainous location, the probability of state intervention decreases. 


\section{Data and research design}

In order to empirically examine the determinants of government intervention in communal conflicts, this study introduces new data on government interventions in response to communal conflicts and covers sub-Saharan Africa, 1989-2010. The dataset builds on data on violent communal conflict taken from the Uppsala Conflict Data Program's Non-State Conflict Dataset (Sundberg, Eck \& Kreutz, 2012) which entails several different types of non-state actors. For the purpose of this study, I focus on 'groups that share a common identification along ethnic, clan, religious, national or tribal lines' which are 'not permanently organized for combat, but at times organize themselves along said lines to engage in fighting, ${ }^{1}$ A conflict is coded as active if it results in at least 25 battle-related deaths in one calendar year. Based on these criteria, my dataset consists of 264 observations of active conflict years.

\section{Figure 1 in here}

The focus on the conflict-year as the unit of analysis, rather than for instance the individual event or a geographically delineated unit, is in line with the theoretical arguments which relate to the state's interests in a specific conflict or conflict dyad. Moreover, in the case of communal conflicts, a conflict episode rarely spans more than one conflict-year; in contrast to the continuous fighting often observed in civil wars, these conflicts more commonly feature brief eruptions of violence (Sundberg, 2008).

\section{Dependent variable}

The dependent variable is state intervention in response to violent communal conflict within its territory. This variable builds on novel data collected by the author for this study. For each active communal conflict year recorded by UCDP, the dataset records interventions by host governments that occur during and after the violence (that is, the dataset covers interventions in

\footnotetext{
${ }^{1}$ The UCDP Non-State Conflict Dataset also includes rebel groups and political parties. Communal conflicts are recorded as 'organizational level 3' in the dataset. For more information see the UCDP Non-State Conflict Codebook (Nilsson \& Pettersson, 2013).
} 
reaction to the conflict; preventive measures were not coded). ${ }^{2}$ I code an intervention when the central government deployed security forces, i.e. when it sent a contingency of military forces, paramilitary troops or special police units to the locality of conflict in reaction to the violence ${ }^{3}$. To be included, this security force deployment had to take place in direct response to the fighting. Deployment of security forces normally took place in direct connection to the violence, i.e. within days of its eruption. My dependent variable intervention is a binary indicator taking the value 1 if the government intervened in the communal conflict that year and 0 if it does not.

The main source for the coding was the Factiva database, which contains news reports from local and global news sources. For each communal conflict, a search was conducted from the first year of active conflict until one year after the end of the period the dataset covers (i.e. last December 2011). ${ }^{4}$ One potential concern is that state interventions in communal conflicts, especially in the periphery of states, are underreported in news sources and reports. However, the same concern holds true for communal conflicts in general, and it is reasonable to assume that if the conflict is reported, so are interventions to end the violence. The risk of under-reporting may be particularly acute with respect to conflicts in remote areas, particularly if they do not see intervention. This would have implications for the test of hypothesis $4 \mathrm{a}$, since it would mean that the effect of remote location is underestimated because remote conflicts without intervention are not identified, resulting in a harder test for this hypothesis.

Figure 2 shows the empirical record of state interventions in response to communal conflict in sub-Saharan Africa 1989-2010. Intervention took place in about $60 \%$ of the cases. The grey line indicates for each year the share of active communal conflicts which were addressed through government intervention.

\section{Figure 2 in here}

\footnotetext{
${ }^{2}$ While a dataset including preventive interventions would be theoretically interesting and increase analytical possibilities, identifying events in a systematic and comparable manner would be very difficult as conflicts which see preventive intervention might not escalate to the level of inclusion in the UCDP dataset.

${ }^{3}$ If there is not a functioning state, the intervention variable is coded as missing and the observation is excluded from the analysis (in effect, this concerns Somalia in 1997-2000 and 2003-2005, based on UCDP coding of the statebased conflict).

${ }^{4}$ The search was conducted in line with UCDP procedure and using the same search terms for interventions; the conflicts were identified using the names of the conflict parties (including all known alternative group names and spellings). Additional information was sought in a number of country-specific sources, such as reports by local NGOs, case studies, etc. More information on the search and coding procedure is provided in the codebook.
} 


\section{Independent variables}

Based on the theoretical framework above, I derived a number of hypotheses about how strategic interests and state capacity affect the likelihood of intervention in local communal conflict.

Hypotheses $1 \mathrm{a}$ and $1 \mathrm{~b}$ proposed that positive and negative bias in relation to the conflict parties should make intervention more likely. To test these propositions, I rely on data from the Ethnic Power Relations (EPR) dataset (Cederman, Wimmer \& Min, 2010). The EPR data identifies politically relevant ethnic groups and codes their access to, or exclusion from, national executive power. To evaluate the hypotheses I include two dummy variables. The first, positive bias, takes on the value 1 if one or both of the groups in the conflict was represented in executive power in the year when the conflict took place. ${ }^{5}$ This is based on the assumption that when an ethnic group involved in local conflict is also represented at the political centre, the government has reason to be partial in relation to that conflict in order to protect its ethnic constituents. Positive bias by this definition is present in $42 \%$ of my observations. The second, negative bias, denotes whether one or both of the groups involved in the conflict was subject to discrimination. ${ }^{6}$ Negative bias by this definition is present in $17 \%$ of my observations. The variables are not mutually exclusive - one side may be subject to positive bias while the other is subject to negative bias (and this is the case in 23 observations). It is important to underline that the dependent variable in this study, state intervention in communal conflict, does not form part of the coding of these variables rather, the EPR variables are coded entirely based on access to central political power.

Furthermore, this operationalization of bias focuses on ethnicity, and may not be able to capture more nuanced patterns of bias and patrimonialism. However, the EPR project's operationalization of ethnicity encompasses several dimensions of ethnic identification including religion, regional belonging, etc. - depending on which cleavages are politically salient in the specific country and time period ${ }^{7}$. Also, the important role of ethnic identity in African politics is widely accepted (e.g. Berman, 1998; Mamdani, 1996; Posner, 2007), and the existence

\footnotetext{
${ }^{5}$ The EPR dataset includes four forms of access to power: Monopoly, Dominance, Senior Partner or Junior Partner (Cederman, Wimmer \& Min, 2010: 100-101). I manually checked the groups involved in my dataset against the EPR data, and coded a 1 for my positive bias variable in all cases where one or both groups in conflict were coded as any of these since all these forms of access to power are considered to constitute a basis for bias.

${ }^{6}$ The EPR dataset contains three additional variables denoting exclusion, but only discrimination is included in my data, based on theoretical considerations. The other three are Regional Autonomy (having access to local but not national power structures), Separatist Autonomy (cases where a group has actively opted out of national power and set up local separatist institutions), Powerless (without being actively discriminated) (Cederman, Wimmer \& Min, 2010: 100-101). However, I do not consider Regional Autonomy and Powerless to be cases that indicate active government bias against the group (and there are no cases of Separatist Autonomy among the groups in my data). ${ }^{7}$ See "Coding rules for types of ethnic markers, EPR Version 3", available at http:/ /www.epr.ucla.edu/
} 
of ethnic ties has been shown to be a strong predictor of intervention and support in other contexts of violent conflict (Saideman, 2001; 2007).

Hypothesis 2a posited that conflicts that revolve around land and local authority are especially likely to be politicized and hence to see state intervention. To test this proposition, I rely on new data from the UCDP which codes the issues at stake in non-state conflicts (von Uexkull \& Pettersson, 2013). This dataset covers Africa 1989-2011 and codes conflict issues along three main categories: authority, territory, and lootable resources. The combination of issues coded can vary across years in the same conflict, and there may be more than one issue coded for each conflict-year. I construct the variable land \& authority which takes the value 1 if the conflict is coded as having both a territory and an authority issue. This is the case in about $20 \%$ of the observations. Hypothesis $2 \mathrm{~b}$ posited that the economic importance of an area may also affect the likelihood of intervention. Hence, I include a measure of the level of local income based on georeferenced income data from G-Econ, which measures per capita GDP at the local level (Nordhaus, 2006). The variable is taken from the PRIO-GRID data structure (Tollefsen, Strand \& Buhaug, 2012) which connects a number of variables to a world-wide spatial grid of cells with a 0.5x0.5 decimal degree resolution. The UCDP Georeferenced Events Dataset (Melander \& Sundberg, 2013) provides geographical references for all communal conflicts, enabling me to match the location of the conflicts to the PRIO-GRID. ${ }^{8}$

Hypothesis 3 a posited that the material and military capacity of the state affects the likelihood of intervention. As a measure of state capacity, I use the CINC score (Composite Index of National Capability) from the Correlates of War project's National Material Capabilities dataset (Singer, Bremer \& Stuckey, 1972). The CINC score is based on a country's military expenditure and personnel size, economic production and population size, and is often employed as a measure of state capacity (e.g. Crescenzi et al., 2011; Salehyan, 2008). The score denotes the country's average of these components as a share of the world total; a higher figure denotes a higher material capacity ${ }^{9}$. Hypothesis $3 \mathrm{~b}$ proposed that other ongoing armed conflicts should affect the resources available for intervention in communal conflict. The variable state-based conflict, from the PRIO-GRID, denotes whether the area where the communal conflict took place was located in a zone of state-based conflict, i.e. armed conflict between a government and a rebel actor, that

\footnotetext{
${ }^{8}$ For cases where an active conflict year consisted of events in more than one grid cell, the location where most the violence (most of the deaths in best estimate) took place was used.

${ }^{9}$ To facilitate interpretation, the index is multiplied by 100 . After rescaling, the countries in my sample score between 0.025 and 0.885 .
} 
year. Similarly, if there are many active communal conflicts, the government may not be able to intervene in all of them. Thus, I include a measure of the number of additional ongoing communal conflicts in the state within the same year of activity (other communal conflicts), based on the UCDP non-state data.

To assess whether the physical location of a communal conflict affects the likelihood of state intervention, as proposed by hypotheses $4 \mathrm{a}$ and $4 \mathrm{~b}$, I employ two variables from the PRIOGRID. First, the variable travel time is used as a measure of the remoteness of the location in relation to urban centres. It denotes the average time of travel (in minutes) from the conflict location to the nearest city with more than 50,000 inhabitants. This is arguably a better proxy for accessibility than for instance the distance to the capital, as the latter fails to account for the existence of security force bases outside of the capital and the type of terrain that needs to be crossed to reach the conflict location (Tollefsen \& Buhag, 2015). Also from the PRIO-GRID, I include the variable mountainous to assess the impact of difficult terrain which may limit the accessibility of the conflict location. ${ }^{10}$

\section{Control variables}

I include two control variables which may be correlated both with the likelihood of intervention, and with one or several of the main independent variables. Firstly, if states need to prioritize intervention in certain conflicts, they are likely to intervene in the most severe cases. If a conflict is allowed to escalate too far, it may spill over into a rebellion against the central state or otherwise constitute a threat to its ability to exercise authority (Brosché \& Elfversson, 2012). Similarly, the decision to intervene may be affected by popular expectations from domestic as well as international audiences to address particularly violent conflicts. Hence, I control for the intensity of fighting, operationalized as the number of deaths in the conflict according to the best estimate of deaths in the year of activity. ${ }^{11}$ The variable intensity $(\log )$ is taken from the UCDP andis log-transformed to reduce the influence of very large values. Secondly, previous engagement in relation to a local conflict may make subsequent intervention more likely. Such effects have been found in research on international interventions into civil war (Mullenbach,

\footnotetext{
${ }^{10}$ Based on data from the United Nations Environment Programme's World Conservation Monitoring Centre UNEP-WCMC (2002), denoting the proportion of the cell that has mountainous terrain.

${ }^{11}$ The variable is not lagged, since the coding of the dependent variable only accounts for interventions in reaction to the conflict violence; furthermore, the previous year in most cases is inactive.
} 
2005). Hence, to control for temporal dependence in the dependent variable, I include the variable previous intervention that takes the value 1 if the government has previously intervened in the same conflict. ${ }^{12}$ Descriptive statistics for all variables are reported in Table I.

Table $I$ in here

12 This variable takes on the value 1 if intervention has occurred previously during the time period, 1989-2010. Conflicts active in 1989 and 1990 (4 observations) were traced back in time to 1987. 


\section{Results and analysis}

In order to test the hypotheses outlined above, I ran a series of logistic regressions where the dependent variable is a binary indicator of whether the government intervenes in the communal conflict or not, with robust standard errors clustered at the country level. The results are presented in Table II below. The first four models separately test each subset of hypotheses together with the control variables, while model 5 includes all the independent variables and controls.

\section{Table II in here}

Hypotheses $1 \mathrm{a}$ and $1 \mathrm{~b}$ posited that bias would increase the likelihood of intervention. Hypothesis 1a receives support: positive bias has a positive and significant effect on the likelihood of intervention, at the 95\% and 99\% confidence level respectively in Models 1 (trimmed model) and 5 (full model), suggesting that governments are more likely to intervene in local conflicts involving groups to which they have political ties. ${ }^{13}$ Hypothesis $1 \mathrm{~b}$, on the other hand, is not supported: negative bias, operationalized as exclusion from political power through discrimination, does not appear to have a statistically significant effect on the likelihood of state intervention. However, when disaggregating the negative bias variable further, the results suggest that if one of the conflict parties is discriminated, intervention is more likely (statistically significant at the $95 \%$ confidence level), whereas if both are discriminated, the effect is instead negative, but not statistically significant (results reported in appendix i, Models 6 and 7). One could hypothesize that in cases of conflict between two discriminated groups, the government is not motivated to make costly intervention. It may be presumed that both conflict parties will become weakened through the conflict, and hence that a cost-benefit calculation in this type of case would favour non-intervention. Meanwhile, if only one side in the conflict is discriminated, it may be more important to intervene in order to ensure a local power relation where that group is relatively marginalized. However, in-depth case study analysis would be needed to ascertain whether this type of explanation holds.

\footnotetext{
${ }^{13}$ Importantly, the results do not tell us if intervention is the result of preferences at the centre, or of local actors using their access to central power to effect a deployment of state resources. However, while theoretically distinct, these processes are commonly two sides of the same coin, especially in states characterized by patrimonial networks, and these mechanisms are very difficult to separate in a cross-national study.
} 
To make interpretation of the results more intuitive, I calculate values of substantive interest using the Clarify software (King, Tomz \& Wittenberg, 2000; Tomz, Wittenberg \& King, 2003). To recall, state intervention is not a rare event: it took place in 157 of 264 observations in the dataset. The calculations based on the results from Model 5, and as a baseline I use a case where all the other variables are set at their median or type value. ${ }^{14}$ In the baseline scenario, a conflict where there is positive bias has a $38 \%$ higher likelihood of intervention than a conflict where there is not (the predicted probability of intervention increases from 0.47 to 0.65). Predicted probabilities are summarized in Table III below.

Hypothesis 2a, which posited that conflict over land and local authority is more likely to see intervention, is evaluated in Models 2 (trimmed model) and 5 (full model). This hypothesis receives strong support: the effect of the variable land \& authority is positive and significant at the $99 \%$ confidence level in both models. Using the same baseline scenario as above, a conflict where there is a conflict issue concerning land and authority has a $64 \%$ higher probability of intervention compared to if the conflict is not about land and authority. Combining conflict issue and bias, I find that in a case where there is simultaneously positive bias and a conflict over land and authority, the probability of intervention is $85 \%$ higher than in a case where there is no bias and the conflict revolves around some other issue. In line with hypothesis $2 b$, the economic importance of a specific area also appears to affect the likelihood of intervention. The effect of local income is positive and significant at the $99 \%$ and $95 \%$ confidence level, respectively, in Models 2 and 5. Substantively, increasing local income from the $25^{\text {th }}$ to the $75^{\text {th }}$ percentile means that the probability of intervention increases from 0.42 to 0.51 (a $21 \%$ increase in probability). If the conflict revolves around land and local authority, increasing local income from the $25^{\text {th }}$ to the $75^{\text {th }}$ percentile raises the probability of intervention from 0.74 to 0.80 .

Hypotheses 3a and 3b are examined in Models 3 and 5. Hypothesis $3 a$ posited that if the central state has strong material capacity, the probability of state intervention increases. This proposition receives support in the trimmed model; a higher CINC score, signifying a stronger material state capacity, is associated with a higher likelihood of intervention (statistically significant at the 95\%

\footnotetext{
${ }^{14}$ This means that the conflict takes place in a state with a CINC score of 0.3 (empirically, this corresponds to Ethiopia in 1995 or Sudan in 2007), where two additional communal conflicts occur during the same year, the conflict takes place in a location that is not affected by civil war and from which is takes about 6 hours to travel to the nearest major town, and about $9 \%$ of the local terrain is mountainous; the conflict does not concern a combination of land and local authority, local income (gross cell product per capita) $=776$ USD (empirically, this corresponds to Moroto district in Uganda around 2000 or central Rift Valley province, Kenya, 2008), and the government is not biased in relation to the conflict actors; finally, the conflict causes 60 deaths and has not seen previous intervention by the state. In this baseline case, the probability of intervention is 0.47 .
} 
confidence level). However, in Model 5 which includes all independent variables, the CINC score is no longer statistically significant. This could be due to correlation with the local income measure. If the latter is dropped from Model 5, the CINC score remains statistically significant; results are reported in appendix i, model 8. Based on the model without local income, increasing the CINC score from the $25^{\text {th }}$ to the $75^{\text {th }}$ percentile increases the probability of intervention by $17 \%$. In line with hypothesis $3 \mathrm{~b}$, the presence of state-based conflict in the area where communal conflict takes place decreases the likelihood of intervention. The coefficient is negative and significant at the 99\% confidence level in Models 3 (trimmed model) and 5 (full model). If there is ongoing state-based conflict in the region where the communal conflict takes place, the likelihood of intervention decreases by $34 \%$. Meanwhile, the number of other communal conflicts does not appear to significantly affect the likelihood of intervention in a specific conflict; the effect is in the hypothesized direction but not statistically significant. ${ }^{15}$

\section{Table III in here}

Hypotheses $4 \mathrm{a}$ and $4 \mathrm{~b}$, which proposed that the probability of state intervention decreases if the conflict takes place in a less accessible location, are evaluated in Models 4 and 5. These hypotheses do not receive support. Travel time to the conflict location (hypothesis 4a) has a negative sign, but not a significant effect in Model 4, and even switches sign in the full model. Mountainous terrain (hypothesis 4b) has a negative effect on the likelihood of intervention, as expected, but it is not statistically significant in either model. It may be that the effect of distance and terrain on the probability of intervention is already incorporated in the conflict outbreak; i.e., communal conflicts may be more likely to erupt in less accessible areas in the first place, thereby obscuring the relationship. As mentioned earlier, it may also be that conflicts that take place in remote areas are underreported, especially when there is no intervention, which would mean that the effect of remote location is underestimated. Finally, it could be that inaccessibility is not enough to dissuade intervention given strategic interests; as illustrated by recent responses by the Kenyan government to violence in Turkana after the discovery of oil in the region. While

\footnotetext{
15 This may not be so surprising since addressing local communal conflict likely requires fewer resources than fighting a civil war. It may be more reasonable to expect a threshold effect depending on the number and intensity of other communal conflicts. In line with this, if the variable is replaced with a dummy for cases with a very high number of communal conflicts (more than 5), it does become statistically significant; results reported in appendix i, Model 9.
} 
remoteness may result in limited security enforcement at a general level, it may not impede security force deployment in reaction to specific high-profile events.

With regard to the control variables, the variable intensity $(\log )$ only reaches statistically significance (at the 95\% confidence level) in Model 1. However, when substituting it with a dummy variable for high intensity conflicts (at least 100 dead) this variable becomes significant also in the full model (results reported in appendix i, Model 10). Hence, high conflict intensity does appear to have an effect on the probability of intervention. Contrary to expectations, previous intervention into the same conflict does not appear to make intervention more likely; this may reflect that strategic concerns change over time or because of power shifts at the political centre.

\section{Robustness checks and extended analysis}

I have run a number of models with alternative variable specifications to ensure the robustness of the findings (full results for these and additional robustness checks are available upon request). Firstly, I tested a series of alternative operationalizations of state bias. Alternative specifications for positive bias based on the EPR data ${ }^{16}$ were all positive and statistically significant, while not substantially altering the results for the other variables in the model. I also ran the models using alternative operationalizations of the conflict issue. When tested separately, both land issues and authority issues have a positive and statistically significant effect on the likelihood of intervention, albeit at slightly lower confidence levels and with weaker effects. This appears to be in line with the argument; local control and land are both related to important strategic interests, and when both occur simultaneously the effect is stronger. Alternative operationalizations of state capacity have also been explored. I ran the models using GDP per capita ${ }^{17}$ as an alternative proxy for state capacity; this variable did not achieve statistical significance in the original model, but does have a positive and significant effect as expected when excluding the local income measure. Substituting the CINC score with a variable measuring regime inconsistency generated similar results. ${ }^{18}$ None of these alternative specifications entailed any substantial changes to the results for the other independent variables, further increasing the confidence in the findings.

\footnotetext{
${ }^{16}$ Respectively, specified as one side favoured; both sides favoured; excluding junior partner status.

${ }^{17}$ Current US dollars; data from the World Bank (2014).

18 The variable durable from the PolityIV data measures the years since the last regime change, which is operationalized as a change of at least three points in the POLITY score (which ranges from -10 to 10) over a period of up to three years (Marshall, Gurr \& Jaggers, 2010: 17).
} 
I also sought to identify the effects of potential outliers. To this end, I dropped countries from the analysis, one by one. In most cases this did not substantially affect the results, but excluding Somalia (which accounts for 16 of the 264 observations) had the effect of making travel time significant at the 95\% confidence level in Model 5. This suggests that Somalia represents an outlier in terms of the relationship between conflict location and the probability of intervention, and that the argument about accessibility of conflict location holds some currency when Somalia is excluded. Finally, since my dataset overlaps with the final years of the Cold War, the end of which may have affected state and non-state actors' strategies (Kalyvas \& Balcells, 2010), I also tried dropping the years 1989-1990 from the analysis. This did not affect the results. Additional robustness checks are provided in an online appendix. 


\section{Conclusion}

What factors motivate government decisions to intervene in local communal conflicts within their territory? While we may generally expect states to address violent conflicts within their territory, such interventions do not always take place. The findings of this study indicate that state intervention into communal conflicts within its own territory is contingent on both motivational and structural factors. Capability, measured both as the overall material capacity of the central government and whether these resources are tied up in fighting an armed insurgency, affects the likelihood of intervention. However, strategic interests must also be taken into account when explaining state interventions in communal conflict. These interests derive from the basic interest of rulers to protect their power base and secure important resources. In line with previous research on communal conflict, the results suggest that ethnic constituencies and control over land are key among such strategic concerns.

Two findings in particular warrant further probing. Firstly, the analysis shows that the conflict issue, i.e. what the communal groups are fighting over, has a bearing on the likelihood of intervention. Conflicts concerning which community should have local authority and control land are more likely to see intervention. This finding resonates with the general observation that land is highly politicized in Africa. For instance, Boone (2014) argues that conflicts concerning valuable land are more likely to escalate to a higher political level, because successive governments have crafted institutions that give them more direct control over these localities. Since the underlying conflict issues also appear to affect responses to communal conflict, the findings also underline the importance of incorporating conflict issues in existing data sets, which will enable more disaggregated analysis of conflict issues. Secondly, ethnic ties also affect the likelihood of intervention: conflicts involving groups represented in executive power, and conflicts where one side is facing discrimination by central authorities, are more likely to see state intervention. These findings are in line with Broschés (2014) argument that biased political elites manipulate local conflicts for their own political purposes. They may also reflect that local elites use their influence at the centre to bring state resources to bear on local conflicts. Further research into the dimensions of state bias in relation to communal conflict should attempt to probe these mechanisms and widen the analysis by looking beyond ethnic ties and trying to distinguish more nuanced forms of bias. 
Overall, the findings of this study should lead us to further problematize the view of the state and its monopoly over coercive force. More specifically, the apparent effect of bias and manipulation on the likelihood of intervention suggests that further research into these dynamics is warranted. For instance, how do vested interests on behalf of the central state affect the quality of intervention? In the longer run, is peace brought about by a biased intervention more or less likely to hold than in cases where the government is perceived as more neutral? How does biased intervention affect local power balances and perceptions about the legitimacy of the intervention and its outcome? These are important questions for future studies in the emerging research on communal conflict.

Data replication: The dataset, codebook, and do-files for the empirical analysis in this article can be found at http:/ / wmw.prio.no/jpr/datasets. All analyses were conducted using STATA 13. 


\section{Reference list}

Abdulahi, Mohammud (2004) The Changing Nature of Pastoral Conflicts in South-Eastern Ethiopia: The Case of the Boran and Digodi Pastoralists. Nairobi: Africa Peace Forum.

Abdulrahman, Imran \& Usman A Tar (2008) Conflict management and peacebuilding in Africa: The role of state and non-state agencies. Information, Society and Justice 1(2): 185-202.

Allen, Chris (1999) Warfare, endemic violence \& state collapse in Africa. Review of African Political Economy 26(81): 367-384.

Bates, Robert H (2008) When Things Fell Apart: State Failure in Late-Century Africa. New York: Cambridge University Press.

Berman, Bruce J (1998) Ethnicity, patronage and the African state: The politics of uncivil nationalism. African Affairs 97(388): 305-341.

Bevan, James (2008) Crisis in Karamoja: Armed Violence and the Failure of Disarmament in Uganda's Most Deprived Region. Geneva: Small Arms Survey Occasional Paper Series.

Boone, Catherine (2003) Political Topographies of the African State: Territorial Authority and Institutional Choice. New York: Cambridge University Press.

Boone, Catherine (2007) Property and constitutional order: Land tenure reform and the future of the African state. African Affairs 106(425): 557-586.

Boone, Catherine (2014) Property and Political Order in Africa: Land Rights and the Structure of Politics. New York: Cambridge University Press.

Brosché, Johan (2014) Masters of War: The Role of Elites in Sudan's Communal Conflicts. Uppsala: Department of Peace and Conflict Research.

Brosché, Johan \& Emma Elfversson (2012) Communal conflict, civil war, and the state: Complexities, connections, and the case of Sudan. African Journal on Conflict Resolution 12(1): 33-60.

Buhaug, Halvard (2010) Dude, where's my conflict? LSG, relative strength, and the location of civil war. Conflict Management and Peace Science 27(2): 107-128.

Cederman, Lars-Erik; Andreas Wimmer \& Brian Min (2010) Why do ethnic groups rebel? New data and analysis. World Politics 62(1): 87-119.

Collier, Paul \& Anke Hoeffler (2004). Greed and grievance in civil war. Oxford Economic Papers 56(4): 563595.

Crescenzi, Mark JC; Kelly M Kadera, Sara McLaughlin Mitchell \& Clayton L Thyne (2011). A supply side theory of mediation. International Studies Quarterly 55: 1069-1094.

de Mesquita, Bruce Bueno; Alastair Smith, Randolph M Siverson \& James D Morrow (2005) The Logic of Political Survival. Cambridge/London: MIT Press Books.

Eck, Kristine (2014) The law of the land: Communal conflict and legal authority. Journal of Peace Research 51(4): 441-454. 
Enwerem, Iheanyi M (1999) An assessment of government's formal responses to ethnic/religious riots, 1980-1990s. In: Ernerst E Uwazie; Isaac O Albert \& Godfrey N Uzoigwe (eds) Inter-Ethnic and Religious Conflict Resolution in Nigeria. Lanham, MD: Lexington Books (121-134).

Fearon, James D \& David D Laitin (2003) Ethnicity, insurgency, and civil war. American Political Science Review 97(1): 75-90.

Fearon, James D \& David D Laitin (2011) Sons of the soil, migrants, and civil war. World Development 39(2): 199-211.

Fjelde, Hanne \& Nina von Uexkull (2012) Climate triggers: Rainfall anomalies, vulnerability and communal conflict in Sub-Saharan Africa. Political Geography 31(7): 444-453.

Fjelde, Hanne \& Gudrun Østby (2014) Socioeconomic inequality and communal conflict: A disaggregated analysis of Sub-Saharan Africa, 1990-2008. International Interactions 40(5): 737-762.

Frank, Emily (2002) A participatory approach for local peace initiatives: The Lodwar border harmonization meeting. Africa Today 49(4): 69-87.

Fratkin, Elliot (1994) Resurgence of inter-pastoralist warfare in Kenya. Paper presented at the American Anthropological Association Annual Meeting, Atlanta, December 1994.

Gates, Scott; Håvard Hegre, Mark P Jones \& Håvard Strand (2006) Institutional inconsistency and political instability: Polity duration, 1800-2000. American Journal of Political Science 50(4): 893-908.

Greiner, Clemens (2013) Guns, land, and votes: Cattle rustling and the politics of boundary (re)making in Northern Kenya. African Affairs 122(447): 216-237.

Herbst, Jeffrey (1996). Responding to state failure in Africa. International Security 21(3): 120-144.

Herbst, Jeffrey (2000) States and Power in Africa: Comparative Lessons in Authority and Control. Princeton, N.J.: Princeton University Press.

HRW (1993) Divide and Rule: State-Sponsored Ethnic Violence in Kenya. New York: Human Rights Watch.

Hutchinson, Sharon E (2001) A curse from God? Religious and political dimensions of the post-1991 rise of ethnic violence in South Sudan. The Journal of Modern African Studies 39(2): 307-331.

Ibrahim, Dekha \& Janice Jenner (1997) Wajir community based conflict management. Paper presented at the USAID Conference on Conflict Resolution in the Great Horn of Africa, June 1997.

Ikpe, Ukana B (2009) The patrimonial state and inter-ethnic conflicts in Nigeria. Ethnic and Racial Studies 32(4): 679-697.

Jackson, Richard (2002) Violent internal conflict and the African state: Towards a framework of analysis. Journal of Contemporary African Studies 20(1): 29-52.

Johansson, Emma (2011) Managing communal conflicts: The role of the state. Paper presented at the 52nd Annual Convention of the International Studies Association, Montreal, March 16-19, 2011.

Kalyvas, Stathis N \& Laia Balcells (2010) International system and technologies of rebellion: How the end of the Cold War shaped internal conflict. American Political Science Review 104(03): 415-429.

King, Gary; Michael Tomz \& Jason Wittenberg (2000) Making the most of statistical analyses: Improving interpretation and presentation. American Journal of Political Science 44(2): 347-361. 
Lund, Christian (2008) Local Politics and the Dynamics of Property in Africa. New York: Cambridge University Press.

Mamdani, Mahmood (1996) Citizen and Subject: Contemporary Africa and the Legacy of Late Colonialism. Princeton, N.J.: Princeton University Press.

Marshall, Monty G; Ted Robert Gurr \& Keith Jaggers (2010) Polity IV Project: Dataset Users' Manual. Vienna, V.A.: Center for Systemic Peace.

Melander, Erik \& Ralph Sundberg (2013) Introducing the UCDP georeferenced events dataset. Journal of Peace Research 50(4): 523-532.

Mkutu, Kennedy (2008) Guns \& Governance in the Rift V alley: Pastoralist Conflict \& Small Arms. Oxford: James Currey.

Mullenbach, Mark J (2005) Deciding to keep peace: An analysis of international influences on the establishment of third-party peacekeeping missions. International Studies Quarterly 49: 529-555.

Newman, Edward (2013) Statebuilding, upheaval, and civil war. In: Edward Newman \& Karl De Rouen (eds) Routledge Handbook of Civil Wars. London: Routledge (173-185).

Nilsson, Marcus \& Therése Pettersson (2013) UCDP Non-State Conflict Codebook Version 2.5-2013.

Uppsala: Uppsala Conflict Data Program.

Nordhaus, William D (2006) Geography and macroeconomics: New data and new findings. Proceedings of the National Academy of Sciences of the USA 103(10): 3510-3517.

Odendaal, Andries (2013) A Crucial Link: Local Peace Committees and National Peacebuilding. Washington, D.C.: United States Institute of Peace Press.

Posner, Daniel N (2007) Regime change and ethnic cleavages in Africa. Comparative Political Studies 40(11): 1302-1327.

Raleigh, Clionadh (2010) Political marginalization, climate change, and conflict in African Sahel states. International Studies Review 12(1): 69-86.

Saideman, Stephen M (2001) The Ties That Divide: Ethnic Politics, Foreign Policy and International Conflict. New York: Columbia University Press.

Saideman, Stephen M (2007) Ties versus institutions: Revisiting foreign interventions and secessionist movements. Canadian Journal of Political Science 40(3): 733-747.

Salehyan, Idean (2008). No shelter here: Rebel sanctuaries and international conflict. The Journal of Politics 70(01): 54-66.

Singer, David J; Stuart Bremer \& John Stuckey (1972) Capability distribution, uncertainty, and major power war, 1820-1965. In: Bruce Russett (ed.) Peace, War, and Numbers. Beverly Hills: Sage (19-48).

Sundberg, Ralph (2008) Collective violence 2002-2007: Global and regional trends. In: Lotta Harbom \& Ralph Sundberg (eds) States in Armed Conflict 2007. Uppsala: Uppsala University (165-190).

Sundberg, Ralph; Kristine Eck \& Joakim Kreutz (2012) Introducing the UCDP non-state conflict Dataset. Journal of Peace Research 49(2): 351-362.

Theisen, Ole Magnus (2012) Climate clashes? Weather variability, land pressure, and organized violence in Kenya, 1989-2004. Journal of Peace Research 49(1): 81-96. 
Tollefsen, Andreas Forø \& Halvard Buhag (2015) Insurgency and inaccessibility. International Studies Review (in press, doi: 10.1111/misr.12202).

Tollefsen, Andreas Forø; Håvard Strand \& Halvard Buhaug (2012) PRIO-GRID: A unified spatial data structure. Journal of Peace Research 49(2): 363-374.

Tomz, Michael; Jason Wittenberg \& Gary King (2003) CLARIFY: Software for Interpreting and Presenting Statistical Results. Version 2.1. Stanford University, University of Wisconsin, and Harvard University.

Touval, Saadia \& I William Zartman (eds) (1985) International Mediation in Theory and Practice. Boulder, Co.: Westview Press.

UNEP-WCMC (2002) Mountain Watch 2002 (http://www.unep-wcmc.org/mountains/mountain_watch/ pdfs/WholeReport.pdf).

von Uexkull, Nina \& Therése Pettersson (2013) What they are fighting for: Conflict issues in African nonstate armed conflicts 1989-2011. Paper presented at the 54th Annual Meeting of the International Studies Association, San Francisco, 3-6 April 2013.

Weber, Max (1948 [1918]) Politics as a vocation. In: H Gerth \& C Wright Mills (eds) From Max Weber. London: Routledge \& Kegan Paul (77-128).

Wilkinson, Steven I (2005) Communal riots in India. Economic and Political Weekly 40(44/45): 4768-4770.

Wilkinson, Steven I (2006) Votes and Violence: Electoral Competition and Ethnic Riots in India. New York: Cambridge University Press.

Wimmer, Andreas (2004) Facing Ethnic Conflicts: Toward a New Realism. Lanham, M.D.: Rowman \& Littlefield Publishers.

World Bank (2014) World Development Indicators (http://data.worldbank.org/data-catalog/worlddevelopment-indicators). 


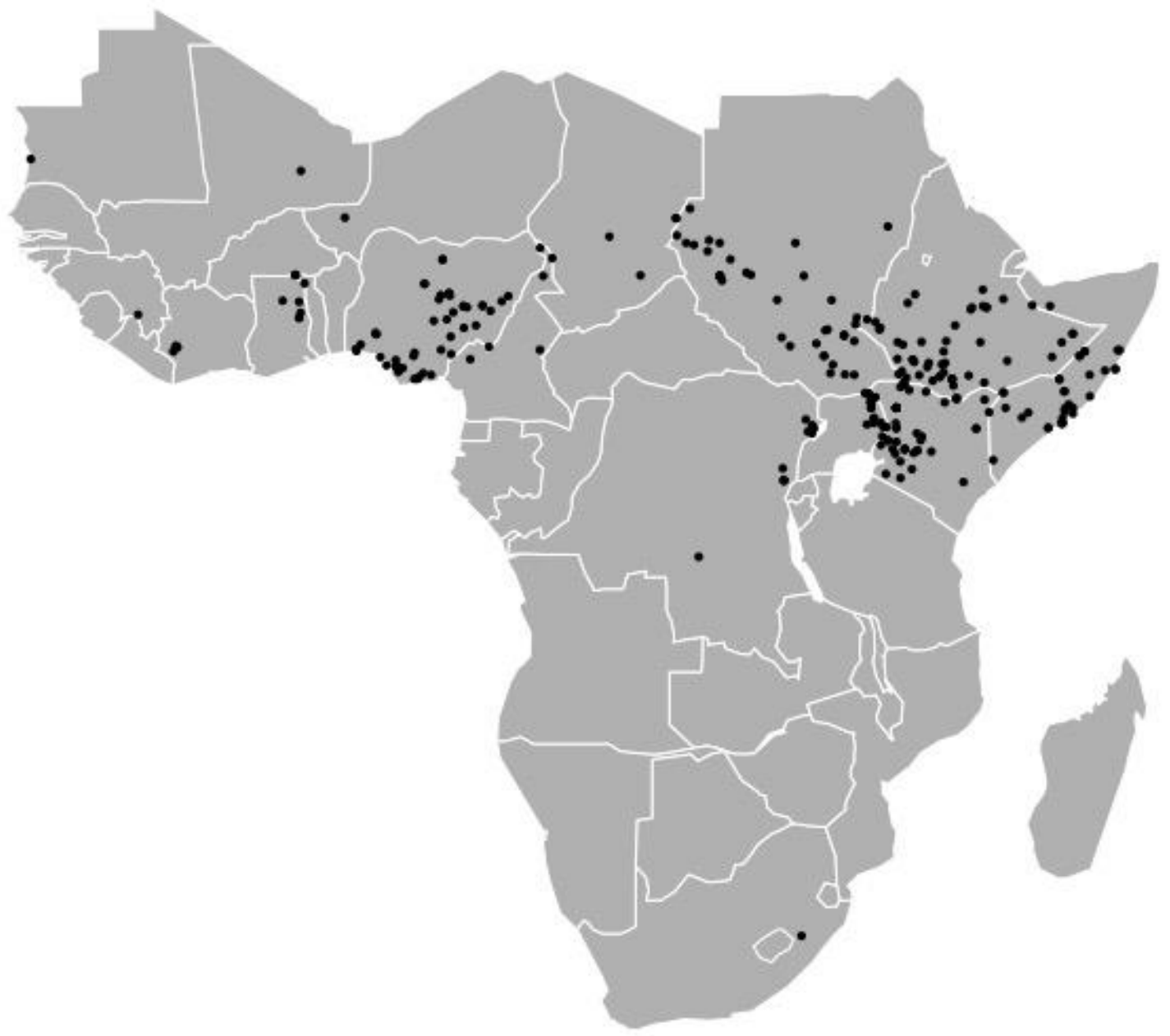

Figure 1. Active communal conflicts, sub-Saharan Africa, 1989-2010 


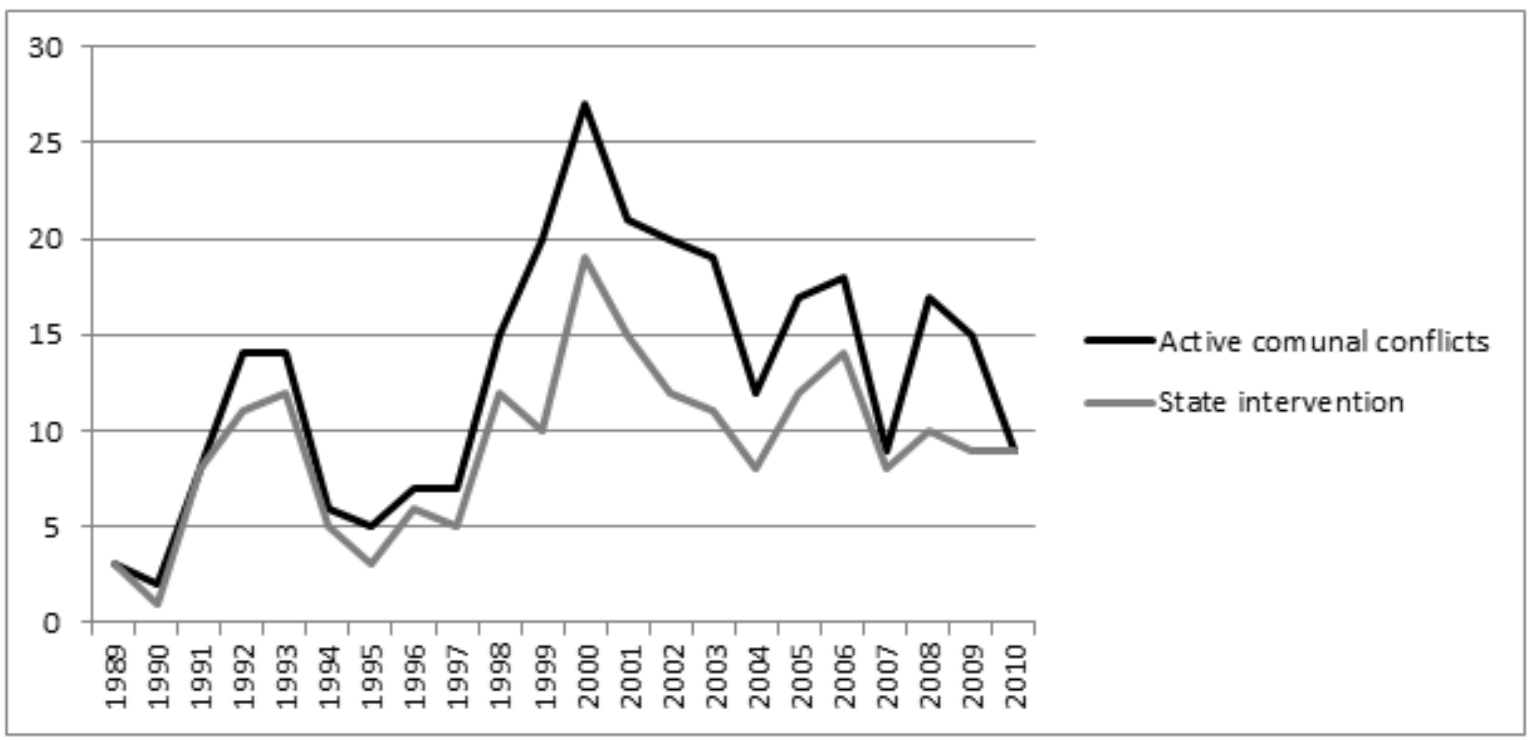

Figure 2. State intervention, sub-Saharan Africa, 1989-2010 


\begin{tabular}{|llllll|}
\hline Table I: Descriptive statistics & & & & & \\
Variable & Obs & Mean & Std. Dev. & Min & Max \\
\hline Intervention & 264 & .595 & .492 & 0 & 1 \\
Positive bias & 264 & .420 & .495 & 0 & 1 \\
Negative bias & 264 & .174 & .380 & 0 & 1 \\
Land \& authority & 264 & .212 & .410 & 0 & 1 \\
CINC score & 264 & .328 & .230 & .025 & .885 \\
State-based conflict & 264 & .330 & .471 & 0 & 1 \\
Other communal conflicts & 264 & 2.822 & 2.577 & 0 & 9 \\
Travel time & 264 & 418.140 & 276.863 & 65 & 1718 \\
Mountainous & 264 & .255 & .302 & 0 & 1 \\
Intensity (log) & 264 & 4.345 & 1.010 & 3.219 & 8.023 \\
Previous intervention & 264 & .178 & .383 & 0 & 1 \\
\hline
\end{tabular}




\begin{tabular}{|c|c|c|c|c|c|}
\hline & \multicolumn{5}{|c|}{ Dependent variable: government intervention } \\
\hline & (1) & (2) & (3) & (4) & (5) \\
\hline Positive bias & $\begin{array}{l}.570^{*} \\
(.261)\end{array}$ & - & - & - & $\begin{array}{l}.750 * * \\
(.235)\end{array}$ \\
\hline Negative bias & $\begin{array}{l}.567 \\
(.391)\end{array}$ & - & - & - & $\begin{array}{l}.428 \\
(.366)\end{array}$ \\
\hline Land \& authority & - & $\begin{array}{l}1.311^{* *} \\
(.387)\end{array}$ & - & - & $\begin{array}{l}1.372^{* *} \\
(.325)\end{array}$ \\
\hline Local income & - & $\begin{array}{l}.001^{* *} \\
(.000)\end{array}$ & - & - & $\begin{array}{l}.001^{*} \\
(.000)\end{array}$ \\
\hline CINC score & - & - & $\begin{array}{l}1.407^{*} \\
(0.685)\end{array}$ & - & $\begin{array}{l}0.237 \\
(0.567)\end{array}$ \\
\hline State-based conflict & - & - & $\begin{array}{l}-.923^{* *} \\
(.201)\end{array}$ & - & $\begin{array}{l}-.669 * * \\
(.199)\end{array}$ \\
\hline Other communal conflicts & - & - & $\begin{array}{l}-.082 \\
(.056)\end{array}$ & - & $\begin{array}{l}-.033 \\
(.049)\end{array}$ \\
\hline Travel time & - & - & - & $\begin{array}{l}-.001 \\
(.001)\end{array}$ & $\begin{array}{l}.001 \\
(.001)\end{array}$ \\
\hline Mountainous & - & - & - & $\begin{array}{l}-.340 \\
(.456)\end{array}$ & $\begin{array}{l}-.348 \\
(.367)\end{array}$ \\
\hline Intensity (log) & $\begin{array}{l}.348^{*} \\
(.161)\end{array}$ & $\begin{array}{c}.226 \\
(.229)\end{array}$ & $\begin{array}{l}.253 \\
(.163)\end{array}$ & $\begin{array}{l}.306^{\dagger} \\
(.172)\end{array}$ & $\begin{array}{l}.245 \\
(.189)\end{array}$ \\
\hline Previous intervention & $\begin{array}{l}.322 \\
(.289)\end{array}$ & $\begin{array}{l}.466+ \\
(.280)\end{array}$ & $\begin{array}{l}.435 \\
(.374)\end{array}$ & $\begin{array}{l}.442 \\
(.353)\end{array}$ & $\begin{array}{l}.421 \\
(.380)\end{array}$ \\
\hline Constant & $\begin{array}{l}-1.494^{\dagger} \\
(.765)\end{array}$ & $\begin{array}{l}-1.545 \\
(.967)\end{array}$ & $\begin{array}{l}-.676 \\
(.810)\end{array}$ & $\begin{array}{l}-.640 \\
(.776)\end{array}$ & $\begin{array}{l}-1.798^{*} \\
(.878)\end{array}$ \\
\hline Observations & 264 & 264 & 264 & 264 & 264 \\
\hline Prob > chi2 & 0.0188 & 0.0000 & 0.0000 & 0.3285 & 0.0000 \\
\hline Pseudo R2 & 0.0420 & 0.0998 & 0.0665 & 0.0286 & 0.1373 \\
\hline
\end{tabular}




$\begin{array}{ll} & \text { P(intervention) } \\ \text { Baseline }^{\S} & 0.466 \\ \text { Positive bias = } 1 & 0.647 \\ \text { Land \& authority = } 1 & 0.770 \\ \text { Positive bias }=1 \text {, land \& authority = 1 } & 0.875 \\ \text { Local income } 25^{\text {th }} \text { percentile } & 0.424 \\ \text { Local income } 75^{\text {th }} \text { percentile } & 0.515 \\ \text { Local income } 99^{\text {th }} \text { percentile } & 0.870 \\ \text { Local income } 25^{\text {th }} \text { percentile, land \& authority = } 1 & 0.738 \\ \text { Local income } 75^{\text {th }} \text { percentile, land \& authority = } 1 & 0.804 \\ \text { Local income } 99^{\text {th }} \text { percentile, land \& authority = } 1 & 0.963 \\ \text { CINC score } 25^{\text {th }} \text { percentile* } & 0.473 \\ \text { CINC score } 75^{\text {th }} \text { percentile* } & 0.554 \\ \text { CINC score } 99^{\text {th }} \text { percentile* } & 0.661 \\ \text { State-based conflict }=1 & 0.308\end{array}$

${ }^{\S}$ Baseline: CINC score $=$ median, other communal conflicts $=2$, state-based conflict $=$ 0 , travel time $=363$ minutes, mountainous $=.088$, land \& authority $=0$, local income $=$ median, positive bias $=0$, negative bias $=0$. Intensity $=60$, previous intervention $=0$. *Based on model 8, appendix (without local income). 